\title{
OCCURRENCE, MOLECULAR IDENTIFICATION AND ANTIBIOTIC RESISTANCE PROFILING OF MYCOPLASMA GALLISEPTICUM AND MYCOPLASMA SYNOVIAE FROM CHRONIC RESPIRATORY DISEASE CASES IN POULTRY BIRDS AND FARM ENVIRONMENT
}

\author{
Abu Baker Siddique ${ }^{1 *}$, Sajjad Ur Rahman², Mazhar Ulhaq ${ }^{3}$, Rasheeha Naveed $^{2}$ \\ ${ }^{1}$ Department of Microbiology, Government College University, Faisalabad-Pakistan 38000, 2 Institute of Microbiology, University of \\ Agriculture, Faisalabad-Pakistan, 38040, ${ }^{3}$ Department of Veterinary Biomedical Sciences, Faculty of Veterinary and Animal Sciences, \\ PMAS, Arid Agriculture University, Rawalpindi, Pakistan 46300, Pakistan
}

${ }^{*}$ Corresponding author, E-mail: absiddique@gcuf.edu.pk

\begin{abstract}
Avian mycoplasmosis is an important risk for commercial poultry production leading to enormous losses in terms of disease and productivity. The main causative agents are Mycoplasma gallisepticum and Mycoplasma synoviae. To study the variable degree of resistance to commonly prescribed and used antibiotics in mycoplasmosis, a total of 115 samples including tissue specimen and swabs were collected from chronic respiratory disease (CRD) cases of broiler and layer birds and their contaminated farm environment. The samples were directly passaged into the Brain Heart Infusion broth (supplemented with $10 \%$ horse serum, NAD, cysteine, penicillin and thallium acetate). Positive samples were transferred to Brain Heart Infusion agar (Difco) for the isolation of Mycoplasma spp. while negative samples were declared after the third passage. Of the samples, $61.5 \%$ were found positive for Mycoplasma spp., which were recovered mostly after second passage. Out of total culture positive cases, Mycoplasma gallisepticum (MG) was identified in 62\% cases and Mycoplasma synoviae (MS) in 38\%, as confirmed through Polymerase Chain Reaction (PCR) using specific primers. The MG and MS isolates showed variable degrees of sensitivity against the commercially available drug of choice, tylosin. The highest Minimum Inhibitory Concentration (MIC) of enrofloxacin $(112.38 \pm 4.34 \mu \mathrm{g} / \mathrm{ml})$ was recorded against MG, followed by tetracyclin $(91.58 \pm 4.66 \mu \mathrm{l} / \mathrm{ml})$, gentamicin $(54.33 \pm 2.98 \mu \mathrm{g} / \mathrm{ml})$, spiromicin $(52.23 \pm 3.99 \mu \mathrm{g} / \mathrm{ml})$ and tylosin $(52.58 \pm 2.69 \mu \mathrm{g} / \mathrm{ml})$. The highest MIC for enrofloxacin $(168.24 \pm 3.82 \mu \mathrm{g} / \mathrm{ml})$ was recorded against MS followed by tetracyclin $(115.48 \pm 2.62 \mu \mathrm{g} / \mathrm{ml})$, spiromicin $(95.96 \pm 2.17 \mu \mathrm{g} / \mathrm{ml})$, tylosin $(84.84 \pm 2.56 \mu \mathrm{g} / \mathrm{ml})$ and gentamicin $(46.4 \pm 2.18 \mu \mathrm{g} / \mathrm{ml})$. MultiplexPCR is a time tested tool for the molecular diagnosis and confirmation of Mycoplasma species.
\end{abstract}

Key words: avian mycoplasmosis; chronic respiratory distress; minimum inhibitory concertation; multiplex polymerase chain reaction

\section{Introduction}

Mycoplasma infections continue to be an important cause of loss in poultry production. The economic consequences are important because of decreased egg production; and growth, and poor hatchability rates due to increased embryo mortality and account for $5-10 \%$ of early chick mortality

Received: 5 July 2018

Accepted for publication: 10 March 2020
$(1,40)$. Mycoplasmosis results in reduced weight gain and feed conversion efficiency along with significant downgrading of carcasses at slaughter due to airsacculitis and arthritis lesions $(2,3)$. Mycoplasmosis is thus a major problem for the poultry industry; and the infections are commonly known as Chronic Respiratory Disease (CRD) of chickens and infectious sinusitis of turkeys (4).

Mycoplasma gallisepticum (MG) is an economically significant pathogen of poultry; and the World Organization of Animal Health (OIE), has declared 
the disease caused by MG as notifiable (1). Mycoplasma synoviae (MS) infection most frequently occurs as sub-clinical upper respiratory problem, and causes air sac lesions when combined with Newcastle Disease, Infectious Bronchitis, or both $(5,6)$. Systemic $M$. synoviae infection results in synovitis, an acute to chronic disease of chickens and turkeys, involving the synovial membrane of joints and tendon sheaths $(7,8)$. In recent reports, Mycopasma synoviae has also been diagnosed as a causative agent of an emerging issue of sharp decline in egg production with eggshell apex abnormalities in poultry $(9,41)$.

In view of the forthcoming World Trade Organization (WTO) recommendations, the establishment of Mycoplasma- free chickens, day old chicks and hatching eggs is needed; otherwise exports will be impossible (10). Control of Mycoplasma infections by vaccination is possible, and various measures are implemented in many countries and control and eradication programs, particularly for MG in breeding stock, are successful. Sometime, chemotherapeutic approaches become necessary to minimize Mycoplasma transmission in cases of outbreaks, as a complement to bio-security measures, in order to minimize economic losses as well as lateral and vertical transmission (8).

Many antimicrobial drug groups, such as macrolides, pleuromutilins, tetracyclines and fluoroquinolones, have been shown to possess inhibitory activity against various mycoplasmas in in-vitro studies (11). However, an increase in resistance of Mycoplasma gallsepticum against tetracyclines $(12,13)$, macrolides $(14,15)$ and quinolones (16) has been reported and treatment strategies have proved unsatisfactory (17).

The current study was aimed at the isolation molecular identification and antibiotic resistance profiling of MG and MS from commercial poultry birds (broilers and layers) and the farm settings / environment.

\section{Materials and methods}

\section{Sample collection}

A total of 115 samples were collected; most from diseased but alive broiler and layer birds showing signs of respiratory distress and other clinical signs were $(n=94)$, and the rest from contaminated farm environments $(n=21)$. Samples from birds included tissues such as trachea and lungs, exudates from air sacs and oral swabs, as well as synovial fluids, while samples collected from farm environment were only swabs from building walls, water drinkers and feeders (18).

\section{Isolation of Mycoplasma species}

The samples were directly inoculated into modified Brain heart infusion (BHI) broth (Difco TM Detroit, United States) as described previously (3), supplemented by $10 \%$ horse serum, NAD, cysteine chloride, penicillin, thallium acetate and phenol red. The samples were incubated at $37^{\circ} \mathrm{C}$ for $24-72$ hours. The negative samples (showing no growth) were further passaged while positive samples were transferred to Brain Heart Infusion agar (Difco) for the successful isolation of Mycoplasma gallisepticum and Mycoplasma synoviae. The isolate identifications were confirmed by the biochemical tests; glucose fermentation, arginine hydrolysis, phosphatase activity, film and spot production, tetrazolium reduction and casein digestion $(19,20)$.

\section{Molecular confirmation}

The DNA from the isolated Mycoplasma spp. was extracted and purified using Phenol Chloroform method (21). The isolated DNA was subjected to multiplex Polymerase Chain Reaction (PCR) using specific primer sequences (22). For MG, the lipoprotein gene was amplified using primer MG-F 5'-GGATCCCATCTCGACCACGAGAAAA-3' and MG-R 5'-CCTTCAATCAGTG: AGTAACTGATGA -3' and for MS, the 16SrRNA gene was targeted using primer MS-F 5'- GAA GCAAATAGTGATATCA- 3' and MS-R 5'- GTCGTCTCGAAGTTAACAA - 3'. The PCR was performed using $50 \mu 1$ of master mix (Vivantis, USA) and $10 \mathrm{pM}$ of each forward and reverse primer. The reaction protocol was optimized as: initial denaturation at $94{ }^{\circ} \mathrm{C}$ for five minutes, followed by 30 cycles of denaturation at $94^{\circ} \mathrm{C}$ for $45 \mathrm{sec}$, annealing at $50^{\circ} \mathrm{C}$ for $30 \mathrm{sec}$, and extension at $72{ }^{\circ} \mathrm{C}$ for $1 \mathrm{~min}$, while final extension was done at $72{ }^{\circ} \mathrm{C}$ for $7 \mathrm{~min}$ in thermal cycler (PeqLab, Germany). The amplified product was run on $2 \%$ agarose gel using $0.2 \mu \mathrm{g} / \mathrm{ml}$ ethidium bromide dye and visualized in gel documentation system (Dolphin Doc, USA) using a 100bp ladder (Vivantis, USA) as DNA marker (23). 


\section{Determination of minimum inhibitory concentrations}

The isolates were subjected to a broth microdilution technique to determine the Minimum Inhibitory Concentrations (MICs) as described previously $(12,24,25)$. Five antibiotics were selected representing different antibiotic classes: enrofloxacin, tetracycline, gentamicin, spiromicin, and tylosin. The assay was performed in 96-well micro-titration plates. Two-fold serial dilutions of the different antibiotics, were made in $50 \mu \mathrm{l}$ modified BHI broth. At the end, $150 \mu$ of broth containing organisms $\left(10^{4}-10^{5} \mathrm{CFU} / \mathrm{ml}\right)$ was added into each well. Two parallel controls were also run, including a control positive (Culture control) containing broth and test culture, and a control negative containing no antibiotic. The minimum concentration of antibiotic that prevented the color change of the medium was taken as theMIC $(15,26)$.

\section{Statistical analysis}

Antimicrobial sensitivity of different types of isolates collected from different types of farms against different types of antibiotics makes a complex design of experiment. Descriptive statistics are presented as the mean of MIC values for different types of isolates for each antibiotic with standard deviation (Table 1). MIC values for both species against similar antibiotics were compared with one-way analysis of variance (ANOVA) and student t-test, with a significance level of 0.05.
In addition, data for each Mycoplasma spp. were analyzed separately with one-way ANOVA at a significance level of 0.01. All data analyses were done by using Minitab ${ }^{\circledR}$ version 16 (Minitab Inc.).

\section{Results}

\section{Isolation of mycoplasma}

Of the 115 samples collected from chronic respiratory disease cases of broiler and layer birds, $61.5 \%$ were positive for Mycoplasma spp. Of these positive cultures, $62 \%$ were positive for Mycoplasma gallisepticum (MG) and 38\% for Mycoplasma synoviae (MS). MG was isolated from tracheae $(40 \%)$, air sacs $(27 \%)$, lungs $(10 \%)$, oral swabs (10\%), feeders /drinkers (8\%), and walls (5\%) (Figure 1). MS was isolated from synovial fluid $(40 \%)$, lungs $(24 \%)$, air sacs $(16 \%)$, tracheae $(12 \%)$, and feeders / drinkers (8\%) (Figure 2).

Maximum recovery of MG from clinically ill birds was observed from tracheas (42\%) and air sacs $(29 \%)$, followed by lungs $(8 \%)$ and oral swabs $(8 \%)$, whereas recovery from the contaminated farm environment was recorded as $8 \%$ from feeder / drinker samples and 4\% from wall samples. In the case of Mycoplasma synoviae, highest recovery was obtained from synovial fluid (40\%) followed by lungs $(27 \%)$, air sacs $(13 \%)$, tracheae $(13 \%)$ and feeder / drinker samples (7\%).

The isolates were confirmed through PCR. Mycoplasma gallisepticum yielded 720bp of PCR product, while $207 \mathrm{bp}$ band size was observed in case of Mycoplasma synoviae (Figure 3).
Figure 1: Isolation of Mycoplasma gallisepticum from different samples collected from broiler and layered birds as well as their farm environment

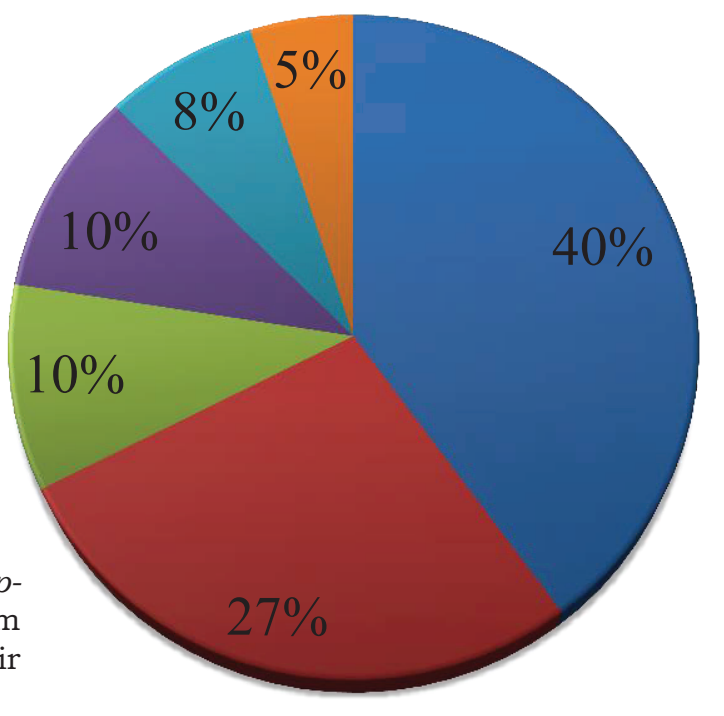

\section{Samples}

- Trachea

- Air sacs

$\square$ Lungs

- Oral swabs

$\square$ Feeder/dinker

$\square$ Walls 

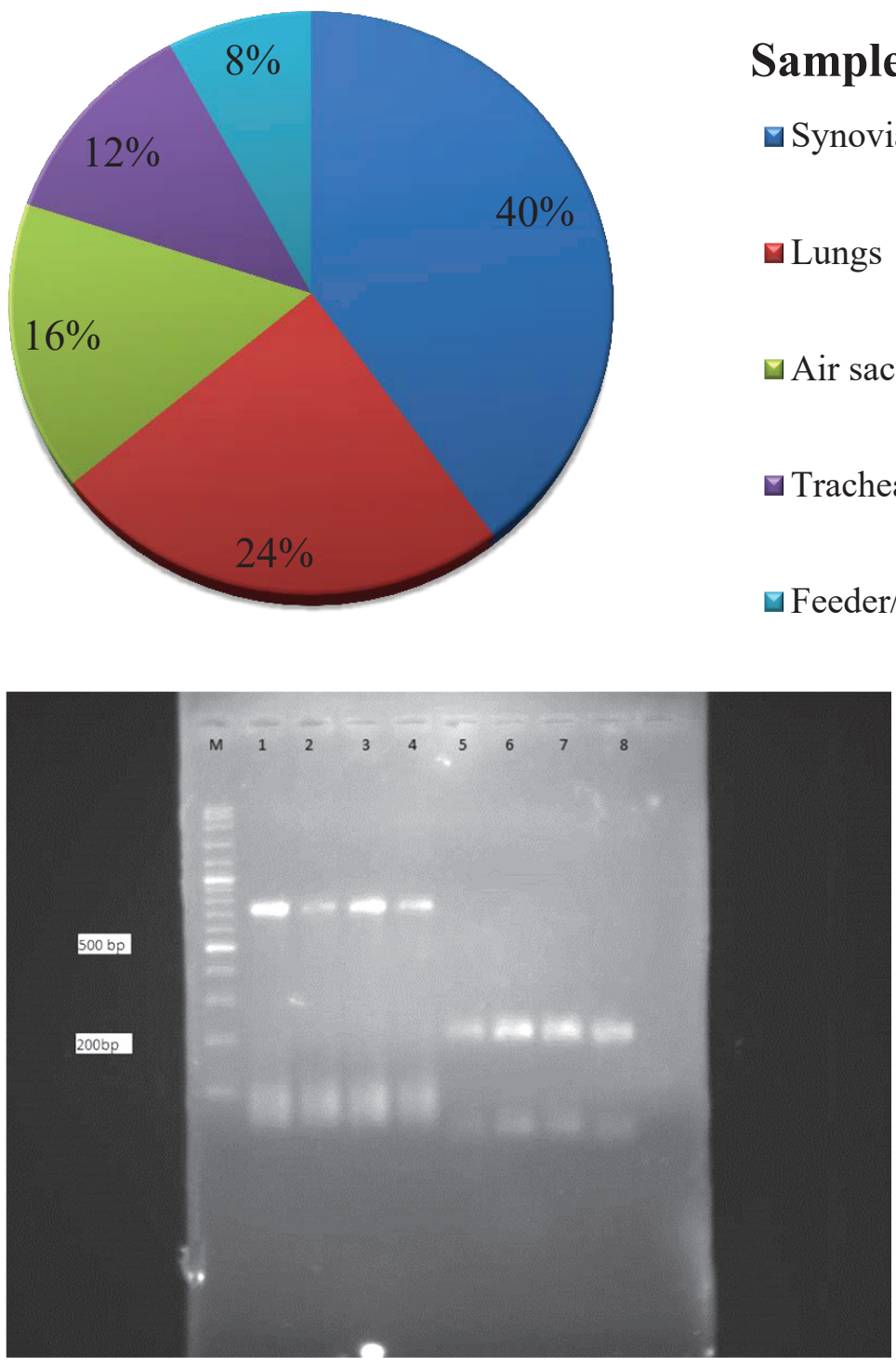

$\square$ Feeder/drinker

\section{Samples}

$\square$ Synovial fluid

DLungs

$\square$ Air sacs

Trachea

Figure 2: Isolation of Mycoplasma synoviae from broiler and layered birds

Figure 3: PCR-based confirmation of isolates. Lane M: Maker 100bp, Lane 1, 2, 3 and 4: positive samples for Mycoplasma gallisepticum, Lane 5, 6, 7 and 8: positive samples for Mycoplasma synoviae

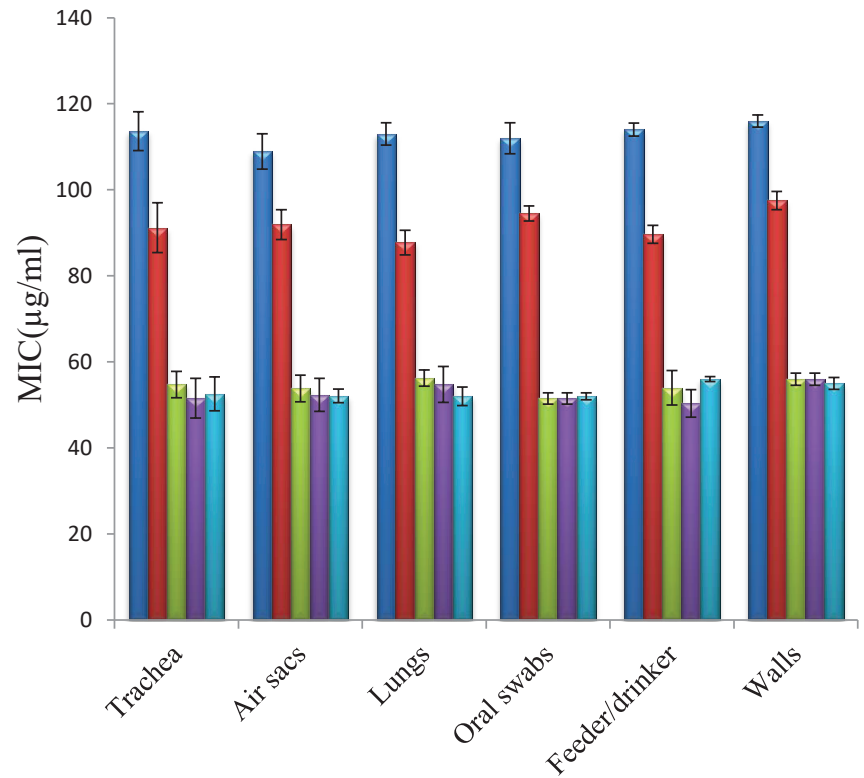

Samples
• Enrofloxacin

घ Tetracycline

$\square$ Gentamicin

$\square$ Spiromicin

$\square$ Tylosin
Figure 4: Minimum Inhibitory Concentration (MIC) of commercially available antibiotics against Mycoplasma gallisepticum isolated from different samples 
Figure 5: Minimum Inhibitory Concentration (MIC) of commercially available antibiotics against Mycoplasma synoviae isolated from different samples

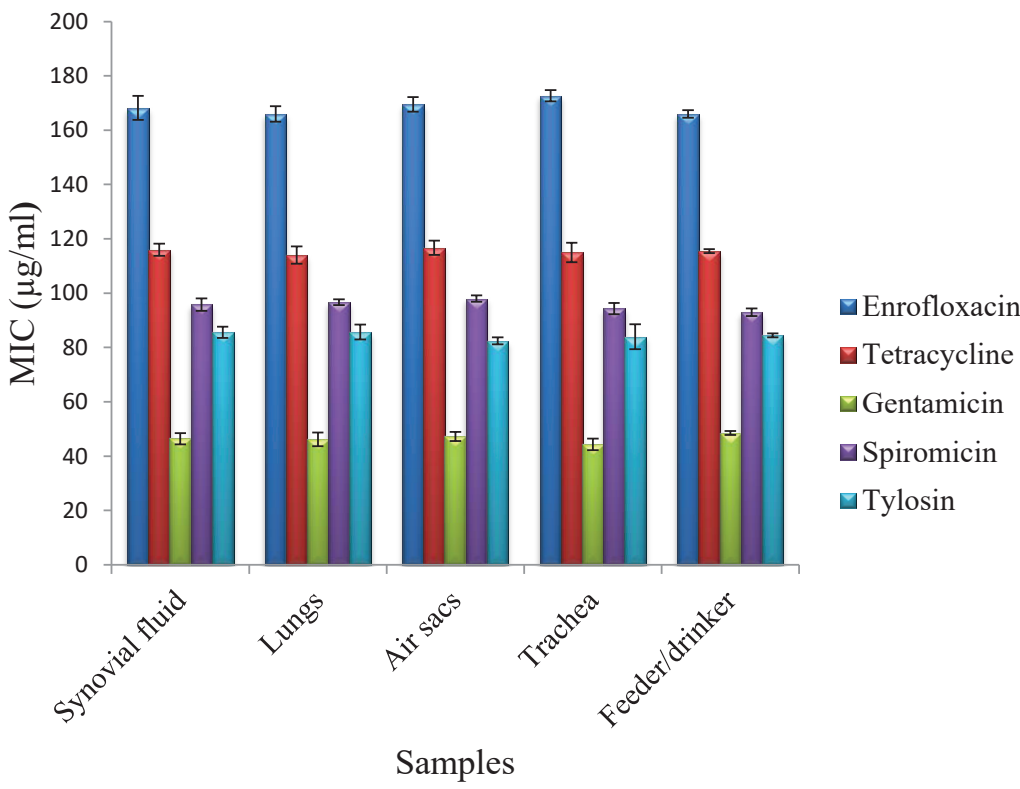

and tylosin against $\mathrm{MG}$ and $\mathrm{MS}$ (Table 1). Statistical analysis with student t-tests $(\mathrm{P}<0.05)$ showed that enrofloxacin, tetracycline, spiromicin and tylosin have greater MIC against MS, while gentamicin has greater MIC against MG.

One-way analysis of variance (ANOVA) showed no significant difference $(\mathrm{P}<0.01)$ in $\mathrm{MIC}$ of enrofloxacin against different isolates of MG. Tetracycline, gentamicin, spiromicin and tylosin also showed the same pattern for different isolates of MG (Figure 4). There were no significant differences $(\mathrm{P}<0.01)$ in the MIC of enrofloxacin against different isolates of MS. Tetracycline, gentamicin, spiromicin and tylosin also showed the same pattern for all isolates of MS. statistical differences $(\mathrm{P}<0.05)$ in the MIC of enrofloxacin, tetracycline, gentamicin, spiromicin

Table 1: Minimum Inhibitory Concentration (MIC) of commercially available antibiotics against Mycoplasma gallisepticum and Mycoplasma synoviae, shown as (Mean $\pm \mathrm{SD}) \mu \mathrm{g} / \mathrm{ml}$

\begin{tabular}{cccc}
\hline Antibiotics & Mycoplasma gallisepticum (n=40) & Mycoplasma synoviae(n=25) & P-value \\
\hline Enrofloxacin & $112.38 \pm 4.34$ & $168.24 \pm 3.82$ & 0.00 \\
\hline Tetracycline & $91.58 \pm 4.66$ & $115.48 \pm 2.62$ & 0.00 \\
\hline Gentamicin & $54.33 \pm 2.98$ & $46.4 \pm 2.18$ & 0.00 \\
\hline Spiromicin & $52.23 \pm 3.99$ & $95.96 \pm 2.17$ & 0.00 \\
\hline Tylosin & $52.58 \pm 2.69$ & $84.84 \pm 2.56$ & 0.00 \\
\hline
\end{tabular}

Means are significantly different $(\mathrm{P}<0.05)$ 


\section{Discussion}

The disease caused by Mycoplasmagallisepticum and Mycoplasma synoviae is known as Chronic Respiratory Distress (CRD), which causes heavy economic losses in the poultry industry by decreasing production and increasing the cost of production via medication expenses (10).

A multiplex PCR has been optimized for successful detection of five of the respiratory tract pathogens including Mycoplasma gallisepticum, Mycoplasma synoviae, Newcastle Disease virus, Infectious Bronchitis virus and Avian Influenza virus $(23,27,28,29)$. Several studies have shown successful detection of individual pathogens, including a multiplex PCR for the detection of Mycoplasma spp. (30) and multiplex RT-PCR for respiratory tract viruses (6).

A PCR assay for detection of the variable heamagglutinin gene (vlhA gene) of $M$. synoviae $(31,32)$ has proved to be a useful tool in the detection and typing of different MS strains. Comparing vlhA-PCR with 16SrRNA-PCR (31) has also shown that in the very early stage of infection the $16 \mathrm{SrRNA}$ procedure is more sensitive than the vlhA method (27).

The development of multiplex PCR for the detection of different pathogenic species of avian mycoplasma in a sample. The above approach is reliable, sensitive and specific and help to reduce the losses due to mycoplasma infections by early and accurate diagnosis of avian mycoplasma species $(22,24,25)$.

The aim of this study was to assess the in vitro antimicrobial susceptibilities of $M$. gallisepticum and $M$. synoviae isolates from broilers, layer birds and the farm premises. In Pakistan, the control strategy for avian mycoplasmosis is largely based on the use of effective antibiotics, which helps in controlling the severity of clinical disease and prevents substantial economic losses. However, it is worth mentioning that administration of antibiotics depends on the dosage and duration of administration; which may fail to completely eradicate these pathogens from the infected flocks.

Mycoplasma gallisepticum and Mycoplasma synoviae have shown sensitivity in vitro to several antimicrobials including, tetracyclines, macrolides, lincosamides, fluoro-quinolones and others (14). PCR confirmed isolates of $M$. gallisepticum and $M$. synoviae were tested using enrofloxacin, tetracycline, gentamicin, spiromicin and tylosin.
The isolates of Mycoplasma gallisepticum showed a variable degree of resistance against the antibiotics tested, with a significantly high $\mathrm{MIC}_{50}$ of Enrofloxacin as compared to other antibiotics tested followed by tetracycline, gentamicin, spiromicin and tylosin. This is similar to the findings reported by Behbahan and co-workers (33) and the findings of $(16,34,36,37)$. On the other hand, a previous study of MG isolates from Israel had increased resistance to enrofloxacin $(26,35)$.

In the case of Mycoplasma synoviae (MS), significantly high MIC against enrofloxacin, followed by tetracycline, spiromicin, tylosin and gentamicin $(46.4 \pm 2.18 \mu \mathrm{g} / \mathrm{ml})$. These findings were similar to those of $(25,38,39)$.

The results of the current study elucidate the significant losses incurred by poultry birds due to high morbidity and mortality, along with production losses. The multiplex PCR is an efficient, reliable and reproducible tool for the rapid confirmation and diagnosis of avian mycoplamosis. The severity of the problem is of utmost importance and needs to be further investigated using classical diagnostic methods, along with latest molecular techniques for assessment of the disease scenario. There is a huge need to update the therapeutic regimen owing to increased antibiotic resistance from time to time.

\section{Acknowledgement}

This research was supported by Higher Education Commission Pakistan under indigenous scholarship program. We thank David A Morrison for his work on the manuscript in proof correcting.

\section{References}

1. OIE. Avian mycoplasmosis (Mycoplasma gallisepticum, M. synoviae). In: Manual of diagnostic tests and vaccines for terrestrial animals. Paris : Office International des Epizooties, 2008: 482-96.

2. Kleven SH, Ferguson-Noel N. Mycoplasma synoviae infection. In: Saif YM, Barnes HJ, Glisson JR, et al., eds. Diseases of poultry. London : Blackwell Publishers, 2008: 845-56.

3. Kleven SH. Control of avian mycoplasma infections in commercial poultry. Avian Dis 2008; 52: 367-74.

4. Luciano RL, Cardoso ALSP, Stoppa GFZ, et 
al. Comparative study of serological tests for $M y$ coplasma synoviae diagnosis in commercial poultry breeders. Vet Med Int 2011; 2011: Art 304349. doi: $10.4061 / 2011 / 304349$

5. Mohana MA, Haider M, Kadhim AH, et al. Molecular diagnosis of avian respiratory diseases in commercial broiler chicken flocks in province of Najaf, Iraq. Sci Res Essays 2013; 8: 1191-5.

6. Yashpal SM, Devi PP, Sagar MG. Detection of three avian respiratory viruses by single-tube multiplex reverse transcription-polymerase chain reaction assay. J Vet Diagn Invest 2004; 16: 244-8.

7. Gabriel SC, Shivaprasad HL, Chin RP. Systemic Mycoplasma synoviae infection in broiler chickens. Avian Pathol 2005; 34: 137-42.

8. Ley DH. Mycoplasma gallisepticum infection. In: Saif, YM, et al., eds. Diseases of poultry. Ames : Iowa State University Press, 2008: 805-33.

9. Jeon EO, Kim JN, Lee HR, et al. Eggshell apex abnormalities associated with Mycoplasma synoviae infection in layers. J Vet Sci 2014; 15: 579-82.

10. Levisohn S, Kleven SH. Avian mycoplasmosis (Mycoplasma gallisepticum). Rev Sci Tech 2000; 19: 425-42.

11. Gautier-Bouchardon AV, Reinhardt AK, Kobisch M, Kempf I. In vitro development of resistance to enrofloxacin, erythromycin, tylosin, tiamulin and oxytetracycline in Mycoplasma gallisepticum, Mycoplasma iowae and Mycoplasma synoviae. Vet Microbiol 2002; 88: 47-58.

12. Hannan PC, Windsor GD, De Jong A, Schmeer N, Stegemann M. Comparative susceptibilities of various animal-pathogenic mycoplasmas to fluoroquinolones. Antimicrob Agents Chemother 1997; 41: 2037-40.

13. Ter Laak EA, Noordergraaf JH, Verschure MH. Susceptibilities of Mycoplasma bovis, Mycoplasma dispar, and Ureaplasma diversum strains to antimicrobial agents in vitro. Antimicrob Agents Chemother 1993; 37: 317-21.

14. Bradbury JM, Yavari CA, Giles CJ. In vitro evaluation of various antimicrobials against $M y$ coplasma gallisepticum and Mycoplasma synoviae by the micro-broth method, and comparison with a commercially-prepared test system. Avian Pathol 1994; 23: 105-15.

15. Hannan PC. Guidelines and recommendations for antimicrobial minimum inhibitory concentration (MIC) testing against veterinary mycoplasma species. Vet Res 2000; 31(4): 373--95.
16. Wu CM, Wu H, Ning Y, Wang J, Du X, Shen $\mathrm{J}$. Induction of macrolide resistance in Mycoplasma gallisepticum in vitro and its resistance-related mutations with domain $\mathrm{V}$ of 23S rRNA. FEMS Microbiol Lett 2005; 247: 199-205.

17. Nicholas RAJ, Ayling RD. Mycoplasma bovis: disease, diagnosis, and control. Res Vet Sci 2003; 74: 105-12.

18. Ahmad A, Khan TA, Kanwal B, et al. Molecular identification of agents causing respiratory infections in chickens from southern region of Pakistan from October 2007 to February 2008. Int J Agr Biol 2009; 11: 325-8.

19. Stipkovits L. Kempf I. Mycoplasmosis in poultry. Rev Sci Tech 1996; 15: 1495-525.

20. Bencina D, Bradbury JM, Stripkovits L, et al. Isolation of Mycoplasma capriculum-like strains from chickens. Vet Microbiol 2006; 112(1): 23-31.

21. Jackwood MW, Hilt DA, Williams SM, et al. Molecular and serologic characterization, pathogenicity, and protection studies with infectious bronchitis virus field isolates from California. Avian Dis 2007; 51: 527-33.

22. Siddique AB, Rahman SU, Hussain I, et al. Frequency distribution of opportunistic avian pathogens in respiratory distress cases of poultry. Pak Vet J 2012; 32: 386-9.

23. Marois C, Gesbert FD, Kempf I. Polymerase chain reaction for the detection of Mycoplasma gallisepticum from environmental samples. Avian Pathol 2002; 31: 163-8.

24. Wang C, Ewing M, A'arabi SY. In vitro susceptibility of avian mycoplasmas to enrofloxacin, sarafloxacin, tylosin, and oxytetracycline. Avian Dis 2001; 45: 456-60.

25. Cerda RO, Giacoboni GI, Xavier JA, Sansalone PI, Landoni MF. In vitro antibiotic susceptibility of field isolates of Mycoplasma synoviae in Argentina. Avian Dis 2002; 46: 215-8.

26. Gerchman I, Lysnyansky I, Perk S, Levisohn S. In vitro susceptibilities to fluoroquinolones in current and archived Mycoplasma gallisepticum and Mycoplasma synoviae isolates from meat-type turkeys. Vet Microbiol 2008; 131: 266-76.

27. Ehtisham-ul-Haque S, Rahman SU, Siddique M, Qureshi AS. Involvement of Mycoplasma synoviae in respiratory distress cases of broilers. Pak Vet J 2011; 31: 117-9.

28. Seifi S, Asasi K, Mohammadi A. Natural co-infection caused by avian influenza H9 subtype and infectious bronchitis viruses in broiler chicken farms. Vet Arh 2010; 80: 269-81. 
29. Yousaf AM, Aradaib IE, Khairalla KMS, Sbdalla MA, Karrar ARE, ElHussein ARM. Evaluation of RT-PCR for rapid detection of Sudanese isolates and vaccine strains of Newcastle disease. Pak J Biol Sci 2005; 8: 418-20.

30. Wang H, Fadl AA, Khan MI. Multiplex PCR for avian pathogenic mycoplasmas. Mol Cell Probes 1997; 11: 211-6.

31. Hong Y, García M, Leiting V, et al. Specific detection and typing of Mycoplasma synoviae strains in poultry with PCR and DNA sequence analysis targeting the hemagglutinin encoding gene vlhA. Avian Dis 2004; 48: 606-16.

32. Harada K, Tanaka MK, Uchiyama M, et al. Molecular typing of Japanese field isolates and live commercial vaccine strain of Mycoplasma synoviae using improved pulsed-field gel electrophoresis and vlhA gene sequencing. Avian Dis 2009; 53(4): 538-43.

33. Behbahan NGG, Asasi K, Afsharifar AR, Pourbakhsh SA. Susceptibilities of Mycoplasma gallisepticum and Mycoplasma synoviea isolates to antimicrobial agents in vitro. Int $\mathrm{J}$ Poult Sci 2008; 7: 1058-64.

34. Reinhardt AK, Gautier-Bouchardon AV, Gicquel-Bruneau M, Kobisch M, Kempf I. Persistence of Mycoplasma gallisepticum in chickens after treatment with enrofloxacin without development of resistance. Vet Microbiol 2005; 106(1/2): 129-37.

35. Gharaibeh S, Al-Rashdan M. Change in antimicrobial susceptibility of Mycoplasma gallisep- ticum field isolates. Vet Microbiol 2011; 150(3/4): 379-83.

36. Jordan FT, Horrocks BK. The minimum inhibitory concentration of tilmicosin and tylosin for Mycoplasma gallisepticum and Mycoplasma synoviae and a comparison of their efficacy in the control on Mycoplasma gallisepticum infection in broiler chicks. Avian Dis 1996; 40: 326-34.

37. Jordan FT. Forrester CA. Ripley PH, Burch DG. In vitro and in vivo comparison of valnemulin, tiamulin, tylosin, enrofloxacin and lincomycin/ spectinomycin against Mycoplasma gallisepticum. Avian Dis 1998; 42(4): 738-45.

38. Le Carrou J, Reinhardt AK, Kemf I, Gautier-Bouchardon AV. Persistence of Mycoplasma synoviae in hens after two enrofloxacin treatments and detection of mutations in the parC gene. Vet Res 2006; 37(1): 145-54.

39. Senties CG, Shivaprasad HL, Chin RP. Systemic Mycoplasma synoviae infection in broiler chickens. Avian Pathol 2005; 34: 137-42.

40. Nascimento ER, Pereira VL, Nascimento MG, Barreto ML. Avian mycoplasmosis update. Braz J Poult Sci 2005; 7(1): e1. doi: 10.1590/ S1516-635X2005000100001

41. Kursa O, Pakuła A, Tomczyk G, et al. Eggshell apex abnormalities caused by two different Mycoplasma synoviae genotypes and evaluation of eggshell anomalies by full-field optical coherence tomography. BMC Vet Res 2019; 15(1): e1. doi: 10.1186/s12917-018-1758-8 
POJAVNOST, MOLEKULARNA IDENTIFIKACIJA IN UGOTAVLJANJE ODPORNOSTI NA ANTIBIOTIKE MIKOBAKTERIJ MYCOPLASMA GALLISEPTICUM in MYCOPLASMA SYNOVIAE IZOLIRANIH IZ KOKOŠI S KRONIČNIMI DIHALNIMI OBOLENJI IN IZ NJIHOVEGA BIVALNEGA OKOLJA

\author{
A. B. Siddique, S. U. Rahman, M. Ulhaq, R. Naveed
}

Povzetek: Ptičja mikoplazmoza je resno težava v perutninski proizvodnji, ki vodi v velike izgube zaradi obolevanja perutnine in posledično povzroča ekonomske izgube. Glavni povzročitelji mikoplazmoz so Mycoplasma gallisepticum in Mycoplasma synoviae. Za preučevanje spremenljive stopnje odpornosti na običajno predpisane in uporabljene antibiotike pri mikoplazmozi je bilo odvzetih skupno 115 vzorcev, vključno z vzorci tkiva in brisom, pitovnih piščancev, nesnic s kroničnimi boleznimi dihal (CRD) in iz njihovega bivalnega okolja. Vzorci so bili preneseni v tekoče gojišče BHI (iz angl. Brain Heart Infusion), z dodatkom $10 \%$ konjskega seruma, NAD, cisteina, penicilina in talijevega acetata. Pozitivne vzorce smo prenesli v agar BHI (Difco) za izolacijo Mycoplasma spp. Vzorci so bili določeni kot negativni po tretji pasaži. Med vzorci je bilo 61,5 \% pozitivnih na prisotnost Mycoplasma spp., ki smo jih večinoma ugotovili po drugi pasaži. Od vseh pozitivnih primerov je bila ugotovljena Mycoplasma gallisepticum (MG) v $62 \%$ primerov, Mycoplasma synoviae (MS) pa v $38 \%$, kar je bilo potrjeno z verižno reakcijo s polimerazo (PCR) z uporabo specifičnih primerjev. Izolati MG in MS so pokazali spremenljivo stopnjo občutljivosti na komercialno dostopno zdravilo tilozin. Minimalna zaviralna koncentracija (MIC) pri MG je bila najvišja pri enrofloksacinu (112,38 $\pm 4,34 \mu \mathrm{g} / \mathrm{ml})$, sledili pa so tetraciklin $(91,58 \pm 4,66 \mu \mathrm{l} / \mathrm{ml})$, gentamicin $(54,33 \pm 2,98 \mu \mathrm{g} / \mathrm{ml})$, spiromicin $(52,23 \pm 3,99 \mu \mathrm{g} / \mathrm{ml})$ in tilozin $(52,58 \pm$ $2,69 \mu \mathrm{g} / \mathrm{ml}$ ). Najvišjo MIC proti MS smo ravno takougotovili pri enrofloksacinu $(168,24 \pm 3,82 \mu \mathrm{g} / \mathrm{ml})$, ki so mu sledili tetraciklin $(115,48 \pm 2,62 \mu \mathrm{g} / \mathrm{ml})$, spiromicin $(95,96 \pm 2,17 \mu \mathrm{g} / \mathrm{ml})$, tilozin $(84,84 \pm 2,56 \mu \mathrm{g} / \mathrm{ml})$ in gentamicin $(46,4 \pm 2,18 \mu \mathrm{g} / \mathrm{ml})$.

Ključne besede: ptičja mikoplazmoza; kronična bolezen dihal; minimalna zaviralna koncentracija; mnogokranta PCR reakcija 